\title{
The Cult of Peter and the Development of Martyr Cult in Rome. The Origins of the Presentation of Peter and Paul as Martyrs
}

\author{
Alan Thacker
}

This paper will examine the early development of the cult of St Peter as martyr in Rome and its relationship to martyr cult in general as it was elaborated in the city before the seventh century. In so doing it will review the ways in which the earliest texts relating to the cult illustrate how this evolving tradition was anchored in Rome through the attachment of various episodes in the life of Peter to specific sites within the city, sites often of long-standing and exceptional importance in Roman public life.

In its early phases, the Petrine cult is often intertwined with that of Paul, so where necessary they will be considered together. The biblical account of the two apostles focuses upon their pastoral and preaching activities, their missionary work and their teaching. Peter and Paul derive their status not from their deaths but from their commissioning as messengers, the one by Christ in his earthly life, the other after Christ's crucifixion on the road to Damascus. The earliest indications that both were thought to have died for their beliefs date from the late first century but give no details of the circumstances in which they met their end. ${ }^{1}$ By the late second century, however, Tertullian could claim that both had been martyred in Rome, Peter crucified like Christ and Paul beheaded like John the Baptist. Early acta were presumably in existence by then and indeed seem to have been expressly mentioned by Tertullian. ${ }^{2}$

1 For an affirmative review of the earliest (pre-20o) evidence that Peter and Paul died in Rome see Bockmuehl (2010), esp. 114-132, where the author focuses upon the so-called First Letter to Clement, which he argues implies that by the end of the first century both apostles were believed to have been martyred in the city. See also Bockmuehl's contribution to this volume. For a more sceptical approach see Moreland (2016), esp. 349-50, 357 .

2 Eastman (2015), esp. 390-401, provides the relevant early references to the apostolic martrydoms. For a succinct summary of the complex early Petrine dossier see Lanéry (2008) 125-31. See also Van den Hoek's contribution to this volume. 


\subsection{The Acts of Peter}

The earliest known explicit and circumstantial presentation of the Roman martyrdom of either saint appears to have been the Greek, so called 'Gnostic', apocryphal Acts of Peter, probably composed between $c .175$ and $c .225 \cdot{ }^{3}$ The original text is now lost but it evidently included accounts of the saint's combat with Simon Magus and his solitary martyrdom (unaccompanied by Paul) in Rome. The final section of a shortened version of these acts survives in Greek, the Martyrium Petri, ${ }^{4}$ and the whole text in several renderings, including the Latin Vercelli Acts, offering accounts of the apostle's earlier miracles and preaching. ${ }^{5}$ The Martyrium Petri circulated independently and may have been regarded as a freestanding text. ${ }^{6}$ It tells of Peter's final contest with Simon Magus and the sorcerer's attempt, viewed by crowds upon the Via Sacra, to demonstrate his powers by flying which ended with his crashing to the ground and subsequent death. Thereafter Peter causes outrage by preaching chastity to the wives of eminent men in Rome, including the prefect, Agrippa, who is urged to arrest him and kill him. Peter is warned by his followers to leave Rome but when fleeing the city he encounters the risen Lord and asks him where he is going. Christ replies that he is going to Rome to be crucified a second time and Peter interprets this as a prophecy of his own forthcoming fate. Peter returns to Rome, is arrested, and Agrippa orders his crucifixion. Peter is taken to the place of execution and preaches beside the cross before being crucified upside down at his own request. He preaches further on the cross and then dies. He is embalmed and buried in a stone sarcophagus by his follower Marcellus. Afterwards, he appears to Marcellus in a vision. This strengthens Marcellus until the arrival of Paul in Rome. The Martyrium ends with Nero, who had wished to punish Peter even more severely, being frightened by a threatening vision and thereafter leaving Peter's followers alone.

Apart from the reference to the Via Sacra the text shows little knowledge of Rome, and does not mention the site of the martyrdom or of the tomb. It does however provide the framework for more elaborate and Rome-centred versions of the death of Peter and is an indication that by then to achieve the

3 Eastman (2015) 1-25; Lanéry (2008) 126.

4 BHG nos $1483-85$.

5 BHL no. 6656; Erbetta (1975-81), II, 142-68.

6 Eastman (2015) 1-3. 
highest status among the Christian dead it was already necessary to have died for the faith. ${ }^{7}$

\subsection{The Acts of Paul}

The Greek text of the martyrdom of Paul is almost certainly early, perhaps dating back to the second century. It shows no knowledge of Roman topography and is focused solely upon Paul and his solitary martyrdom. ${ }^{8}$ A Latin revision of this text, attributed to Linus, was in existence by the fifth or early sixth century. While it includes a resurrection miracle and an account of Paul's teaching after being sentenced, the telling of the actual martyrdom is brief. After his decapitation Paul presents himself to Nero in a threatening vision; in conclusion the resurrected Paul, like Christ, appears at dawn to his former guards at his unlocated tomb. ${ }^{9}$

\subsection{The 'Catholic' Tradition}

The texts discussed above are focused on one or other of the apostles, each depicted as martyred alone. But from an early date, at least the third century, there was also another, the so-called 'catholic', tradition, in which the apostles are united in a common martyrdom in Rome. That, as we shall see, in turn gave place to a different tradition within the corpus of Roman texts. ${ }^{10}$

The Development of the Petrine and Pauline Cults in Rome: the Evidence of Later Acta

2.1 Pseudo-Linus' Acts of Peter and the Passio SS Processi et Martiniani Another recension of the apocryphal Greek Acts of Peter, diverging in several respects from the version transmitted by the Vercelli Acts, was the parent of two texts. One, Pseudo-Hegesippus, dates from the late fourth-century and, although offering a couple of perfunctory references to Paul, focuses almost exclusively upon Peter. It records the combat with Simon Magus, in particular, the competition over the resurrection of an imperial relative, and the martyrdom of the apostle. ${ }^{11}$ For our purposes the more significant text is the Latin adaptation of the Greek Acts ascribed to Pope Linus, which clearly represents

7 Cf. Ignatius of Antioch (c. 35-107?); Tertullian (c. 150-220); Origen (writing c. 235); Grigg (2004) 8-26.

$8 \quad B H G$ nos 1451-52; Eastman (2015) 121-37.

$9 \quad B H L$ no. 6570; Eastman (2015) 139-69.

10 Lanéry (2008) 126, 129-30; Lanéry (2010) 15-369, at 120-1.

11 BHL, nos 6646-6653; Ussurani (1932) III, 2 (pp. 183-7); Lanéry (2008) 127-30. 
a later stage in the development of the Petrine legend. ${ }^{12}$ Centred upon Peter and taking as its starting point the period after the combat with Simon Magus, Pseudo-Linus appears to have been written for a Roman audience; that is evident both from its strong emphasis on the pre-eminence of Rome and from certain topographical and personal details. It includes one of the earliest references - probably indeed as we shall see the earliest of all - to Peter's incarceration in the custodia Mamertini, the Mamertine prison on the Capitoline Hill known to the ancients as the Tullianum..$^{13}$ It also mentions Peter's prison guards, naming them as Processus and Martinianus and gives the precise location of Peter's death. A particularly interesting episode is Peter's miraculous production of water for the baptism of the guards. Warning Peter that Agrippa is seeking to destroy him, Processus and Martinianus comment that 'after you baptized us as believers in this region of the Mamertine prison ... in a spring brought forth from the stone by prayers and the glorious sign of the cross, you went about as freely as you pleased. ${ }^{14}$ They add he would be similarly free now were it not for Agrippa; so because he, Peter, liberated them from the chains of sin and of demons, he should now depart free from prison and being fettered with chains. ${ }^{15}$ As we shall see, the theme of Peter's baptismal miracle seems to make an early appearance in the iconography, and - rather later - the chains play a prominent part in the cult.

The date of this text has been much debated. References to certain doctrinal formulations make it unlikely that it was composed before the later fourth century, but the details about Peter's guards and his place of imprisonment suggest that it was later still. Pseudo-Linus's use of the term custodia Mamertini, hitherto unknown, coincides with, or slightly predates, its sudden appearance in a number of passiones none of which is earlier than the sixth century. ${ }^{16}$ Most notable among these is the Passion of Processus and Martinianus, which tells of their guardianship of both Peter and Paul and adds a further forty-seven prisoners to the number of those baptized in the Mamertinum. ${ }^{17}$ Again the date

12 BHL no. 6655; Eastman (2015) 27-65.

13 For the Tullianum-Mamertinum, see Steinby (1993-2000) I, 236-9; Fortini (2002).

14 Nam postquam nos credentes in hac vicina Mamertini custodia, fonte precibus et ammirabili signo crucis de rupe producto, in sanctae trinitatis nomine baptizasti, licentiose quo libuerat perrexisti et nemo tibi fuit molestus ...: Eastman (2015) 40-1.

15 nos [Processus et Martinianus] oramus te [Petrum] ... ut quia nos a peccatorum et daemonum vinculis absoluisti, a carcerali et compedum nexibus ... liber ... abscedas: Eastman (2015) 40-3. A similar account appears in the Acts of Sts Processus and Martinianus (BHL, no. 6947); Franchi de' Cavalieri (1953) 48-9; below.

16 Verrando (1983) 419-21. For the early references to the Mamertinum see Franchi de' Cavalieri, (1953) esp. 15-21; Lanèry (2010) 221.

17 Franchi de' Cavalieri (1953) 47-9; Amore (1968) col 1139. 
of the text is controversial, but - although this was once doubted - Verrando's careful analysis has shown conclusively that it post-dates Pseudo-Linus and it has been assigned to the period $514-50 .^{18}$ Interestingly, while it presents both Peter and Paul as joint agents of the conversion of the guards and prisoners, it is Peter alone who elicits water from the rock, performs the baptisms and celebrates the initiates' first mass - evidence that the emphasis on Peter's primacy continued to be strong after Pseudo-Linus composed his acta. ${ }^{19}$

The names of the apostolic guards derive from the titulars of a church outside the walls on the Via Aurelia, known to have existed by the end of the fourth century. ${ }^{20}$ There is, however, no evidence that they were then identified as having any such role. Given that their passio postdates the work of Pseudo-Linus, the duo's appropriation to the Petrine legend is first apparent in the latter. That text, it has been plausibly suggested, is best regarded as a product of the conflicts of the Laurentian schism (498-506). ${ }^{21}$ The anomalous emphasis on Peter alone, even though the association with Paul is an early and strongly Roman one, is perhaps explicable in terms of Pope Symmachus being based at the Vatican, while between 502 and 506 his rival Laurence controlled the Lateran and indeed most of the churches of Rome. Those churches presumably included St Paul's on the Via Ostiense, the likely centre of the production of a rival text similarly focused on a single apostle, the Acts of Paul again attributed to Pseudo-Linus. ${ }^{22}$ Moreover, the Laurentians probably also controlled the church of Sts Processus and Martinianus which lay on the Via Aurelia not far from the cult site of St Pancras, where Symmachus had built (or was to build) a basilica. Contemporary ecclesiastical politics could well have tempted Pseudo-Linus to interpret the earlier iconography of the apostle's imprisonment (discussed below) in such a way that the Laurentian saints were enrolled in a Petrine legend that buttressed Symmachus's party with its base at the Vatican. ${ }^{23}$ That the story, as told by Pseudo-Linus and later elaborated by the Passio of the two saints, was indeed regarded as doubtful is perhaps suggested by the fact that even as late as the end of the sixth century Gregory the

18 Verrando (1983) 419-22, followed by Lanėry, who dismisses suggestions that the passage in Pseudo-Linus relating to the gaolers, Processus and Martinianus, was a later addition to an existing text, pointing out that there is no sign of any such interpolation in the manuscripts: Lanèry (2010) 216-23.

19 Franchi de' Cavalieri (1953) 48.

20 See the anonymous, fifth-century treatise Praedestinatus, $P L$ 53, cols 529-672, at 616; Valentini and Zucchetti (1940-53) II, 151-2; Verrando (1983) 424.

21 Verrando (1983) 415-16, 422-26; Lanèry (2010) 218-19. For other hagiography produced at this time see Verrando (1982) esp. 106-9; idem (1981) esp. 108-12.

22 LP I, pp. xxviii, 43-46; Verrando (1983) 425.

23 Verrando (1983) 424-26; Leyser (2000) 304; Lanèry (2010) 218-19; LP no. 53. 
Great could ignore it when preaching in their church on the vigil of their feast. While referring to the titulars as martyrs, ${ }^{24}$ to the wonders performed by their relics, and to their miraculous appearance in the church Gothorum tempore, the pope makes no mention of their association with St Peter. ${ }^{25}$ It seems likely that this was not because he was unaware of that aspect of the Petrine legend but rather because he regarded the story as a late fabrication. ${ }^{26}$

In addition to the prison story Pseudo-Linus gives certain cultic details. In particular, he refers to the site of Peter's crucifixion as the place called the Naumachia iuxta obeliscum Neronis in montem. The term 'naumachia' which relates to a marine amphitheatre, designated two edifices across the Tiber; Pseudo-Linus appears to have been referring to the Naumachia Trajani which lay to the north of the Castel Sant'Angelo and which may have replaced a previous structure by Domitian on or near the same spot. ${ }^{27}$ His use of the term in this context is an innovation, clearly anachronistic. Significantly the site of the martyrdom is not so named in the Liber Pontificalis, compiled perhaps some thirty years later. ${ }^{28}$ The term 'naumachia', however, also appears in both the Latin and Greek accounts of the joint passion of the two apostles, discussed below. ${ }^{29}$

Pseudo-Linus identifies the otherworldly figure who warned Nero to leave Christians alone as Peter himself and mentions other visionary appearances of the saint. But he follows the early acta in evincing no interest in a tomb cult and does not even mention the location of the tomb itself. It was, it seems, the martyrdom that was all important. In this respect, he provides a crucial

24 Though without actually naming them.

25 The sermon, given in the basilica of Sts Processus and Martinianus on 1 July, the vigil of the feast day of the two saints, gives no biographical details at all: Étaix et al (2005-8) no. XXXII, cap 6: Ad sanctorum martyrum corpora consistimus, fratres mei. Numquid isti carnem suam in mortem darent, nisi eis certissime constitisset esse vitam pro qua mori debuissent? Et ecce qui ita crediderunt, miraculis coruscant. Ad extincta namque eorum corpora viventes aegri veniunt et sanantur, periuri veniunt et daemonio vexantur, daemoniaci veniunt et liberantur. Quomodo ergo vivunt illic ubi vivunt, si in tot miraculis vivunt hic ubi mortui sunt. The miraculous appearance is cap. 7 .

26 For Gregory's ambivalent attitude to Roman martyr cult and to the gesta see Leyser (2000) 289-307.

27 Valentini and Zucchetti (1940-53) I, 144, 182. They note that according to Suetonius the Vatican Naumachia was first constructed by Domitian next to the Tiber and then demolished to make way for the restoration of the Circus Maximus. Trajan reconstructed it on the same site or nearby and dedicated it in 109. Cf. Richardson (1992) 265-6; Steinby (1993-2000) III, 338-9 thinks it improbable that the Naumachia Domitiani corresponded to the Naumachia Trajani.

28 Verrando (1983) 421-22; LP nos 1, 22; below.

29 Eastman (2015) 262-305. 
elucidation of the Quo vadis story. Presenting Christ's appearance to Peter as a vision, he notes that when Peter came to himself he understood the exchange as a reference to his own impending passion: 'The Lord was going to suffer in him - the Lord who suffers in the elect by the compassion of his mercy and the celebration of their glorification. ${ }^{30}$ In other words, the crucial condition for glorificationis celebritas, for the feast-day of a saint, was that it was preceded by martyrdom; the implication is that Peter by his passion had become not just a divinely commissioned leader and teacher of the faithful, he had been assimilated into, had become leader of, the glorious band of martyrs.

\subsection{The 'Catholic Tradition' and Pseudo-Marcellus}

Such sentiments may be compared with another development in which the passions of Peter and Paul are brought together. This, the so-called 'catholic' tradition, makes an early appearance in the texts in the Passion of Nereus and Achilleus, which may well date from the later fifth century. ${ }^{31}$ This 'epic passio', which strings together accounts of several saints, includes a letter purporting to have been sent to Nereus and Achilleus by Peter's disciple Marcellus in which he relates Peter's early conflict with Simon Magus and alludes to its resumption after a year in concert with Paul, by then in Rome. Marcellus is made to declare that 'I thought it superfluous to teach you what you (already) know, since St Linus wrote the full account of their martyrdom in Greek text for the eastern churches'. ${ }^{32}$ As Lanéry has pointed out, this cannot be a reference to a Greek antecedent of the Latin Pseudo-Linus, since that text is focused solely on Peter. ${ }^{33}$ There are, however, closely related texts, in Latin (ascribed to the same Marcellus) and in Greek, in which Paul is associated with Peter in the final conflict with Simon Magus and in which the passions of the two apostles are brought together. ${ }^{34}$ The texts are so similar that one must be a rendering of the other but there is uncertainty over which came first. Most recently it has been argued that, since the Greek version shows some evidence of transliteration from Latin, Pseudo-Marcellus probably represents the original. ${ }^{35}$ Both were written for a Roman audience, at an uncertain date, Pseudo-Marcellus

\footnotetext{
30 quod in eo Dominus esset passurus, qui patitur in electis misericordiae compassione et glorificationis celebritate: Eastman (2015) 44-5.

31 Lanéry (2010) 113-38.

32 Rescriptum Marcelli (BHL, no. 6059), AA SS Maii III, 9-10, at 10: superfluum habui vos docere quod nostis, cum Sanctus Linus Graeco sermone omnem textum passionis eorum ad Ecclesias orientales scripsit. Translation: Lapidge (2017) 219.

33 Lanéry (2010) 120, n. 248.

$34 B H L$, nos 6657-9; BHG, nos 1490-1; Eastman (2015) 221-315; Lanéry (2008) 130-1.

35 Eastman (2015) 223.
} 
certainly being in existence by the later sixth century, when it was used by the author traditionally identified as Pseudo-Abdias. ${ }^{36}$ The Greek text interestingly offers a more elaborate account of the martyrdom of Paul and places it ad aquas Salvias rather than the traditional site on the Via Ostiensis. ${ }^{37}$ Both texts exhibit a first-hand knowledge of the topography of Rome and conclude with an episode that stresses Rome's superior claim over the East to be the resting place and focus of cult of the two apostles. They present an image of apostolic 'harmony', while making it clear that the ultimate leadership of the Christians lay with Peter. That might suggest that they date from the later fifth century, though other later periods seem possible.

The Latin text begins with Paul being brought to Rome under guard and meeting Peter, while its Greek counterpart gives more preliminary details about Paul's adventures. Both present Peter and Paul as preaching harmoniously together and being jointly involved in the contest with Simon Magus, though Peter is given the leading role. ${ }^{38}$ They relate that Simon conjures devils to assist him in flying until the demons' power is broken by Peter and the sorcerer crashes to the ground on the Via Sacra breaking into four pieces which turn into four stones and which 'remain to the present day to commemorate the apostolic victory.'39

Outraged by the death of his friend, Nero orders that Peter and Paul be bound in chains and executed in the Naumachia, but Agrippa, the prefect entrusted with the task, intervenes to ensure that Paul suffers the more merciful fate of decapitation. That penalty is said to have taken place beside the Via Ostiense. ${ }^{40}$ Peter, in accordance with Nero's original commands, is crucified in the Naumachia and his body buried 'under a terebinth tree next to the amphitheatre in the place that is called the Vatican.41

The final episode in the text is an account of an attempt by some Greeks to steal the bodies of the two apostles. They are pursued and overcome by the people of Rome, who wrest the bodies from them and deposit the remains 'in the place which is called Catacumba, on the Appian road at the third

\footnotetext{
$36 \quad B H L$, nos 6663-4; Eastman (2015) 67-101; Lanéry (2008) 131.

37 Eastman (2015) 306-7.

38 See the explicit affirmation that Peter was chosen first by the Lord in the Greek text: Eastman (2015) 300-1.

39 qui sunt ad testimonium victoriae apostolicae usque in hodiernum diem: Eastman (2015) 260-1. Cf. the Greek account, 304-5; see below pp. 269-70.

40 Eastman (2015) 264-5.

41 sub terebinthum iuxta Naumachiam in locum qui appellatur Vaticanus: Eastman (2015) 266-7. Cf. Greek text, 308-9.
} 
milestone'.42 There they remain for a year and seven months until they are retrieved and taken ceremoniously to their respective final resting-places 'in the Vatican at (near) the Naumachia' and 'on the Ostian way at the second milestone', 43 where both authors conclude that many blessings were done through the prayers of the apostles. ${ }^{44}$ While it has been argued that this episode could well reflect Roman defensiveness in relation to the prestige and power of the eastern patriarchates, Pseudo-Marcellus's intentions in general seem more local: to explain and weave stories around cult sites in Rome associated with the apostles. That extends not only to the three apostolic basilicas, but also to the relic stones on the Via Sacra. Their existence is confirmed by Gregory of Tours, who clearly knew the legend of the contest with Simon Magus but offered a rather different explanation for the stones' origin. ${ }^{45}$ All this makes it the more interesting that neither Pseudo-Marcellus nor the Greek Acts make any reference to Peter's baptism of his guards. Pseudo-Marcellus presents Peter as referring to the Quo vadis story, but that is all. That perhaps suggests that these texts predate the ascription of apostolic associations to the Mamertinum or to the church of Processus and Martinianus.

One other near contemporary witness to these traditions is the earliest recension of the Liber Pontificalis, compiled $c .535,{ }^{46}$ the first entry of which is devoted to Peter, treated as bishop of Rome. The compiler relates that Peter held many debates with Simon Magus before the emperor Nero and that he was crowned with martyrdom along with Paul in the thirty-eighth year after Christ's passion. He adds that the apostle was buried on the Via Aurelia at the temple of Apollo, near where he had been crucified and Nero's palace on the Vatican. ${ }^{47}$ That account sits rather uneasily with a story in the biography of Pope Cornelius (251-53) who is said to have been responsible for the removal of the bodies of Peter and Paul from the catacombs and to have transferred that of Peter to the Vatican; again, however, the site is identified as close to the place where the apostle had been crucified, at the temple of Apollo on the Mons Aureus at Nero's palace. ${ }^{48}$ In a third reference, in the biography of Pope

42 in loco qui dicitur Catacumba via Appia milario tertio.

43 in Vaticano Naumachiae, in via Ostiense miliario secundo.

44 Eastman (2015) 268-9. Cf. Greek text, 312-13.

45 Krusch (1885) 53-4 (In Glor. Mart, cap. 27); below.

46 The earliest recension is lost, although its text can be reconstituted partially from epitomes; the existing (second) recension is no later than the 540s: Davies (1989), pp. ii-iii, vii-ix, xxxvii-xxxviii; Geertman (2009), 37-107.

47 LP no. 1 (I, pp. $5^{1-3}, 118$ ). Nero's palace on the Vatican is imaginary, but the temple is now thought to be the Phrygianum, the sanctuary of Cybele at the Vatican: Duchesne, LP I, pp. 119-20, n. 13; Liverani (2006a, 2006b, 2008); Giordani (2001). 
Silvester (314-35), the complier relates that the emperor Constantine built the basilica of St Peter over the tomb of the apostle, in this instance mentioning only the temple. ${ }^{49}$ This manner of identifying the site of Peter's tomb appears to be unique to the Liber Pontificalis, and distinct from the near-contemporary accounts in Pseudo-Linus and Pseudo-Marcellus. ${ }^{50}$ Like both these authors, however, the compiler of the Liber Pontificalis seems more interested in associating the apostolic body with the site of the martyrdom than in the tomb itself.

\subsection{Conclusions}

The acta traditions point to the apostles' martyrdoms as the foundation of their cult in Rome. The primary emphasis is on the sites where they suffered rather than the tombs in which they were buried. The city was sanctified as much by their activities within it, above all by the shedding of their blood there, as by possession of their bodies: the funerary memoria are expressly associated with the location of the martyrdoms. The continuing vitality of these traditions is shown by their various reworkings and elaborations in a succession of acta. The texts not only deploy the Petrine legend for specific politico-ecclesiastical purposes, they also illustrate its progressive embedding in Roman topography.

To provide a context for these writings it is necessary to turn back to the early development of martyr cult in Rome. The earliest surviving calendar of martyrial commemorations in and around Rome is the Depositio martyrum, which includes, beside Christmas and Peter's chair, twenty-four martyrial feast days, some with celebrations at more than one place. At the same time a similar calendar of episcopal depositions from Lucius (d. 254) down to Sylvester I (d. 335) was also compiled. ${ }^{51}$ While it seems more than probable that ecclesiastical authorities associated with Pope Mark (d. 336) were responsible for both these lists, they were clearly part of a wider and developing consciousness of Rome's status as a Christian city. In 354 both sets of Depositiones ${ }^{52}$ were included in the Chronographia which the celebrated calligrapher Filocalus compiled for a wealthy Roman patron called Valentinus, perhaps a member of the

\footnotetext{
49 LP, no. 33 (I, pp. 78-9, 176).

$5^{\circ}$ An interpolated version of Pseudo-Marcellus, dependent on the Actus Silvestri and LP, equates the temple of Apollo with the Vatican: Lipsius and Bonnet (1891), I, 176.

51 LP I, pp. 10-12.

$5^{2}$ The bishops updated to include Mark and Julius I (d. 352).
} 
Symmachus family; they formed part of a wide range of comparable almanaclike information, which included the birthdays of the Caesars, the official civil calendar of Rome, lists of Roman consuls, prefects, popes, and the fourteen regions of the city, and a chronicle of Rome. ${ }^{53}$ Valentinus was almost certainly a Christian and the Chronographia is evidence of the degree to which martyrial feast days were coming to be thought of as an element of Romanness, even if as yet Christianity was not fully integrated into the public life of Rome and its aristocracy.

In its most famous entry, on 29 June, the Depositio martyrum calendars the joint feast of Peter in catacumbas on the Via Appia and Paul on the Via Ostiensis. This was a specifically Roman commemoration; in the East the joint feast was celebrated from the fourth century on 28 December, as recorded by Gregory of Nyssa (d. c. 395) and in the Syriac calendar of $411 .^{54}$ The Depositio unequivocally places Peter and Paul among the martyrs, yoking them together as suffering death on the same day and thereby forming one among several martyrial doublets in the calendar. Although the significance of the cult site ad catacumbas is famously problematic, graffiti found there provide clear evidence that, as the Depositio asserts, it had been the scene of cultic activity since the later third century, including funerary feasts, refrigeria, at which the apostolic martyrs were evidently invoked. All this confirms the early and Roman origin of the 'catholic' tradition that the two apostles were martyred on the same day. 55

The Depositio places Peter and Paul jointly at the heart of emerging martyr cult in Rome. The crucial developments in this process, however, came later in the fourth century. Pope Damasus' activities in promoting Rome's martyrs both within the city and in the intramural cemeteries have been much discussed and can only be touched on briefly in this paper. ${ }^{56}$ Here it is necessary simply to stress that the pope's role needs to be considered in relation to the role of the Christian aristocracy in Rome. The presence of Christian grandees and high imperial officials - men such as Junius Bassus, Olybrius and Petronius Probus - was much felt at the great imperial basilicas, including St Peter's, and they clearly set the tone for burial $a d$ sanctos and the commemoration of the dead. ${ }^{57}$ Damasus, operating with the co-operation of local patrons, focused attention on the martyrs themselves and their tombs. That seems to have involved

\footnotetext{
53 Salzman (1991).

54 Eastman, (2011) 23, n. 20.

55 For a recent discussion see Nieddu (2009). See also Van den Hoek's contribution to this volume.

$5^{6} \quad$ See most recently Trout (2015).

57 See McLynn (2012); Thacker (2013).
} 
a good deal of imaginative recreation, since the famous epigraphic poems set up at the allegedly martyrial tombs reveal how little he had to go on. And, of course, it involved a very considerable expansion in the number of martyrs created. Some eleven of the surviving poems commemorate saints for the first time $^{58}$ and even extend to inscriptions celebrating large groups whose names and identities were unknown. ${ }^{59}$ The fashion for martyrial doublets already apparent in the Depositio, was further developed in the feasts represented in the epigrams and it is perhaps worth pondering their significance, especially in relation to the presentation of Peter and Paul as founders of Christian Rome. ${ }^{60}$

Damasus's contribution to the development of the cult of Peter and Paul has to be set in the context of this wider martyrial sponsorship. Although he published a poem celebrating Paul's biblical doings, ${ }^{61}$ Damasus does not appear to have set up any inscription at the tomb basilica on the Via Ostiensis. At St Peter's the texts by which the pope proclaimed his presence were not at the heart of the imperial basilica but related to a landscaping and canalization project on the Vatican and to a baptistery. ${ }^{62}$ Where Damasus did proclaim the martyrial cult was of course ad catacumbas, in the basilica apostolorum, on the Via Appia, where perhaps tellingly the two apostles were no longer believed to reside. In the famous epigraphic poem Hic habitasse, he asserted that it was on account of their blood (that is to say their martyrdom), that Peter and Paul reached the heavenly realms and it was that same blood (shed of course in Rome) that gave the city, though they were sent from the East, the right to claim them as citizens. ${ }^{63}$ This is an explicit declaration that the apostles' martyrial status was absolutely essential to, indeed the foundation of, their Roman cult. ${ }^{64}$ Clearly while this might be regarded as a way of pre-empting the primatial claims of the equally Petrine see of Antioch, ${ }^{65}$ it was also part of current thought about martyrs in Rome. The same notion was expressed in other poems including the epigram relating to Saturninus, in the cemetery of Traso, which states that although he was an inhabitant of Carthage the

\footnotetext{
$5^{8}$ Trout (2015) Elogia 6, 7, 8, 15, 21, 28, 31, 42, 43, 44, 49 .

59 Trout (2015) Elogia 42 (unknown martyrs), 43 (62 martyrs), both in the cemetery of Traso. For Damasus see also Noble's contribution to this volume.

6o Cf. Leo I's assertion of their superiority to Romulus and Remus, below.

61 Trout (2015) Elogium 1.

62 Trout (2015) Elogia 3-4; Thacker (2013) 145 and references therein.

63 Trout (2015) Elogium 20: discipulos oriens misit, quod sponte fatemur;/ sanguinis ob meritum Christumque per astra secuti/ aetherios petiere sinus regnaque piorum:/ Roma suos potius meruit defendere cives./ haec Damasus referat vestras nova sidera laudes.

64 For the importance of martyr cult to Damasus and his successors and especially of the twinning of Peter and Paul as martyred patrons of Rome see Sághy (2015).

65 As argued for example by Chadwick (1962).
} 
shedding of his blood (in Rome) changed his homeland, his name and his race, and made him a Roman citizen. ${ }^{66}$ That the emphasis on the martyrial status of Rome's apostles had imperial endorsement is evident in the remodelling of the Pauline basilica on the Via Ostiense begun by Theodosius I; the enormous new building was focused on the saint's tomb, enclosed in a memoria which proclaimed Paul's status as both martyr and apostle and probably functioned as a mensa for the pouring of libations as well as an altar. ${ }^{67}$

Prudentius shows the impact of Damasus's enterprise especially clearly, envisaging Rome as the city of innumerable martyrs, who were its guardians and protectors. He was especially impressed by the sixty unknown martyrs buried under one massive stone on the Via Salaria, presumably those commemorated in Damasus's epigrams at the cemetery of Trason. ${ }^{68}$ At the heart of this burgeoning cloud of witnesses sit Peter and Paul. In the Peristephanon, in his poem on St Lawrence, Prudentius calls on Christ to grant that Rome may become Christian and as sureties for this invokes the two princes of the apostles, who reign there. In the same poem he expressly presents Peter and Paul as the saviours of Rome; they have displaced Jupiter - Paul banishes him hence, the blood of Peter drives him out. ${ }^{69}$ By implication they have become the presiding patrons of a refounded Rome. ${ }^{70}$ In another poem celebrating the two apostles, which clearly reveals knowledge of their deaths as recorded in the early Greek Acta, Prudentius depicts their joint feast day as a major event in Rome, the festival of triumphal martyrdoms which he believed were separated by exactly one year. The refounding theme is further pursued in his rumination upon the Tiber, viewed as consecrated both by its washing of the marshlands soaked in martyrial blood and by the hallowing of both its banks through the sacred tombs on either side. ${ }^{71}$

Prudentius, then, confirms that Rome was regarded as having been refounded and protected through the blood of its unnumbered martyrs at the head of which stand Peter and Paul. Similar sentiments were expressed in the hymn attributed to Ambrose which refers to Rome as 'founded by such blood'72 and

66 Trout (2015) Elogium 46: sanguine mutavit patriam nomenque genusque./ romanum civem sanctorum fecit origo.

67 Fillipi (2009a) esp. 37-40); idem (2009b); Eastman (2011) 36-42. The two surviving inscribed lastra of the memoria read Paolo apostolo mart(yri).

68 Prudentius, Perist. 2.530-2, 541-4; 11.13-6. Edition: Thompson (1949-1953); Trout (2015) Elogium 43 (see also Elogium 42); Thacker (2007) 37-8.

69 Prudentius, Perist. 2.457-72. Cf. Dijkstra's contribution to this volume, pp. 3-4.

$70 \quad$ Elsewhere Paul is termed Salvator generis Romulei: Prudentius, c.Symm. praef. 80.

71 Prudentius, Perist. 12.

72 Ambrose, hymn 12,23: fundata tali sanguine: Duval (1992) 525. The hymn seems to privilege Peter as founder. 
by Paulinus of Nola, who asserted that the city had been saved, when Stilicho defeated invading Germans, by the presence of Paul and Peter, grandees proceres - of Rome, along with all the city's other martyrs. ${ }^{73}$ Although the divine commissioning of Peter and Paul as princes of the apostles is always recognized, it is the martyrial status that they share with Rome's other saints that underpins their guardianship.

In the mid fifth century this theme of Rome's unique claim to the apostles' especial patronage, by virtue of being the location of their martyrdom underpinned the wide-ranging primatial claims made by Leo I in his sermons. By then Peter was clearly coming to overshadow Paul in papal thought. Thus in a sermon preached on the anniversary of his consecration, Leo grounded his own authority on Peter's unceasing authority in his see which itself derived not only from Christ's commission but also from the powers of patronage which a martyr acquired through his suffering. ${ }^{74}$ In another sermon preached on June 29 Leo urged the Romans that they had uniquely special reasons to make much of the apostles' feast:

Yet today's feast must be revered with a special celebration of its own for our city, beyond the respect it deserves from the rest of the world. Where the death of the leaders of the apostles has been covered with glory, there should be the chief place of joy on the day of their martyrdom..$^{75}$

73 Paul. Nol., carmen 21,27-34: Pluribus haec etenim causa est curata patronis/ ut Romana salus et publica uita maneret;/ hic Petrus, hic Paulus proceres, hic martyres omnes/ quos simul innumeros magnae tenet ambitus Urbis/quosque per innumeras diffuso limite gentes/ intra Romuleos ueneratur Ecclesia fines:/ sollicitas simul impenso duxere precatu/ excubias: Dolvec (2015) 464; trans. Walsh (1975).

74 Sermon 5.4: Nam si omnibus fere ubique martiribus pro susceptarum tollerantia passionum, hoc ad merita ipsorum manifestanda donatum est, ut opem periclitantibus ferre, morbos abigere, inmundos spiritus pellere et innumeros possint curare langores; quis gloriae beati Petri tam imperitus erit aut tam invidus aestimator, qui ullas Ecclesiae partes non ipsius sollicitudine regi, non ipsius ope credit augeri? 'Nearly all the martyrs in every place have been granted - as a reward for enduring the sufferings they underwent and in order to make known their merits - the ability to help those in danger, to drive away sicknesses, to expel unclean spirits, and to cure infirmities without number. Who then will be so unacquainted with the glory of the blessed Peter or so begrudging in their estimation [of it] as to believe any segment of the Church not guided by his watchful concern or endowed with his help?': Chavasse (1973); trans. Freeland and Conway (1993) 32. Cf. Chadwick (1962).

75 Chavasse (1973), Sermon 82.1: Verumtamen hodierna festivitas, praeter illam reverentiam quam toto terrarum orbe promeruit, speciali et propria nostrae urbis exsultatione veneranda est, ut ubi praecipuorum apostolorum glorificatus est exitus, ibi in die martyrii eorum sit laetitiae principatus; trans. Freeland and Conway (1993) $35^{2}$. 
He goes on, significantly, to invoke Peter as the founder (inter alia) of the church in Antioch, 'where the dignity of the name of Christian first arose' but then notes that it was Peter who thereafter 'bore the trophy of the cross of Christ in the Roman citadel', where by the divine plan he had been preceded by the honour of Christ's power and the glory of his suffering. ${ }^{76}$ For Leo, as for Damasus, the location of that martyrdom was a decisive factor in Rome's primacy.

\section{$4 \quad$ Early Iconographical Evidence Relating to the Apostolic Martyrdoms}

How do the texts just considered relate to other forms of evidence for the cult of the apostle-martyrs in Rome? Early frescoes in the catacombs suggest that Peter and Paul begin to be distinguished from the rest of the twelve apostles in the mid-fourth century. Particularly interesting is a fresco in the vault of the arcosolium of Celerina in the cemetery of Praetextatus, which depicts a youthful Christ in a central medallion with on the right Paul and Peter and on the left Sixtus II (corresponding to Paul) and a now lost figure, probably Lawrence ${ }^{77}$ or Timothy, ${ }^{78}$ corresponding to Peter. ${ }^{79}$ Outside the arcosolium is a figure labelled Liberius, presumably the mid fourth-century pope, who, it has been suggested, was paired on the other side of the entrance arch with another then popular Roman martyr, Hyppolytus. ${ }^{80}$

76 Chavasse (1973) sermon 82.5 (version $\beta$ ): Iam Antiochenam Ecclesiam ubi primum Christiani nominis dignitas est orta, fundaveras, ... tropaeum crucis Christi Romanis arcibus inferebas, quo te divinis praeordinationibus anteibant et honor potestatis, et gloria passionis; trans. Freeland and Conway (1993) 355. Cf. sermon 83.1.

77 Peter and Paul appear with Lawrence and Sixtus in a gold glass from the catacombs: Morey (1959) no. 240 (Peter, Paul, Lawrence, Sixtus, Cyprian). Cf. no. 344 (Peter?, Paul, Lawrence, Timothy). The two apostles also feature in Prudentius' poem on Lawrence: Perist. 2.457-72.

78 Timothy is paired with Sixtus on three surviving gold glasses (Morey (1959) nos. 55, 74, 313) while Lawrence appears with Sixtus only twice, once in a glass on which Timothy also appears in a lower register (nos. 240 and 344). Timothy's connection with Sixtus is unknown.

79 The images are head first towards Christ with their feet pointing to the outer wall.

8o Dagens (1986) 327-81; for Hippolytus see Morey (1959) nos. 38 (fragment with Peter and Timothy), 240 (with Peter, Paul, Lawrence, Sixtus and Cyprian), 278 (with Sixtus), 344 (with Timothy). For another image with these saints see the fresco in catacomb of St Januarius at Naples. Cf. also a fresco dating from around 400 in the catacomb of Peter and Marcellinus. This depicts Christ enthroned, flanked by Peter on the right (from the standpoint of the viewer) and Paul on the left, with four smaller figures below, named as the martyrs with whom the catacomb was especially associated: (from viewer's left): 
Such an iconographical programme presents Peter and Paul as essentially Roman figures keeping company with popular local martyrs - those whose images appear especially frequently on late fourth-century gold glass votives from the catacombs. A considerable number of these discs, which are presumed to have formed the bases of drinking vessels used in refrigeria in the catacombs, show one or more Roman martyrs. ${ }^{81}$

Peter and Paul are by far the most commonly represented, but if we look a little more closely quite a complex pattern emerges. The two apostles are most frequently shown facing each other, often accompanied by a wreath or crown to commemorate their joint victory over death through martyrdom. ${ }^{82}$ That image clearly points to their standing as the joint patrons of the city as a whole and even perhaps as the heirs or supplanters of earlier civic cult. ${ }^{83}$ On a number of occasions they appear with other martyrs, sometimes together, sometimes separately. Paul several times occurs alone, but Peter never, except in a couple of scenes representing his striking of the rock. ${ }^{84}$ Of the other Roman martyrs, the most often represented is Agnes, whose iconography may be compared with that of the apostles. Generally she appears alone, as an orant; ${ }^{85}$ there are, however, two scenes of her flanked by Peter and Paul, one of them a striking image in which she towers over the two apostles. ${ }^{86}$ Such evidence suggests that, while there was a commonly adopted official imagery

Gorgonius, Peter, Marcellinus, Tiburtius and Gordianus: Huskinson (1982) 10-11, citing Nestori (1975) no. 3 (p. 48).

81 See Morey (1959); Thomas (2015); Walker (2017).

82 E.g. Morey (1959) nos. 37, 50, 51, 53, 56, 60, 61, 63, 65, 66, 67, 286, 314. This imagery could affect other Roman saints, e.g. no. 74 (Sixtus and Timothy shown facing one another, in concordia, with a figure holding crowns over their heads).

83 The Romanness of the cult was emphasized by Leo I: Isti sunt sancti patres tui verique pastores, qui te regnis caelestibus inserendam multo melius multoque felicius quam illi discordes usque ad parricidium gemini condiderunt, (version $\alpha$ ), quam illi quorum qui tibi nomen dedit fraterna te caede foedavit (version $\beta$ ). 'These selfsame men are your holy fathers and true shepherds, who built you up to be a part of the holy kingdom better by far and much more favourably than those twins quarrelling to the point of murder, than those of whom the one, who gave you your name, defiles you with the murder of his twin brother': Chavasse (1973) sermon 82.1; trans. Freeland and Conway (1993) 353. A third version (Chavasse, $\gamma$ ) adds a further clause, quam illi quorum prima studio moenium tuorum fundamenta locata sunt: 'than those by the zeal of whom the first foundations of your walls were established'.

84 Morey (1959) nos. 80-1; discussed below.

85 Morey (1959) nos. 82, 84, 85, 121, 124, 221, 226, 246, 248, 412, 425 (?, fragment). In no. 265 she appears with Mary and in no 283 she is orant flanked by Christ and Lawrence.

86 Morey (1959) nos. 75, 83. 
which depicted Peter and Paul as guarantors of Rome's privileged civic status, there might be more personal reactions to the dual cult, treating them primarily as local Roman martyrs and associating them with their peers. In the two Agnes discs, indeed, the imagery seems to reflect a votary wishing at the very least to underline Agnes' equality with the apostles as protector of the city.

The frescoed arcosolia and the gold glass votives represent the world of the affluent middle classes of late antique Rome. To an altogether grander world belong the Christian sarcophagi, on which Petrine imagery first emerges in the early fourth century. ${ }^{87}$ The relevant iconography has been fully discussed elsewhere in this volume ${ }^{88}$ and here I wish only briefly to comment on the scenes of Peter's arrest and of Peter striking the rock. Peter's arrest has generally been presumed to represent his committal to prison in Rome, before his martyrdom, a subject known from the earliest apocryphal literature. Those responsible for such imagery seem to have avoided depicting shameful death by crucifixion whereas they did not shy away from Paul's death by the sword, already known by the mid fourth century. ${ }^{89}$ When it appears in 359 , on the magnificent sarcophagus of Junius Bassus, together with the explicit depiction of the martyrdom of St Paul and counterbalancing the arrest and passion of Christ, the Petrine arrest is implicitly martyrial..$^{90}$ By the end of the century the inclusion in the scene of a soldier bearing a cross makes the meaning more explicit, ${ }^{91}$ and eventually this depiction of Peter on the via crucis developed into an image of Peter carrying the cross - as on the Pola casket, an ivory box probably used to contain relics and almost certainly made in Rome in the early fifth century. ${ }^{92}$ We can detect here, then, a development in the iconography. The earliest versions could just as well have been read as Peter's arrest in Jerusalem as related in Acts, where he is said to have been kept under military guard and on the occasion of his release to have been asleep between two soldiers. ${ }^{93}$ The later representations, however, make it clear that Peter is on the road to martyrdom and hence have a specific Roman context.

87 Discussed by Huskinson (1982) 13-31. See also Van den Hoek's contribution to this volume and Dijkstra (2016).

88 See the contributions of Löx, for Peter's arrest, and Dresken-Weiland.

89 See, e.g., the sarcophagus found in the confessio of the Theodosian basilica, which also shows a balding Paul bound with his hands behind his back facing a Roman soldier. For the date see Rep. I no. 61: second third of the fourth century; Donati (2000) cat. no. 48 (pp. 126, 207-08): 340-6o; Utro (2009a) 57-63; idem (2009c), 122-4: 340-50. Eastman assigns to it a later, Theodosian, date: Eastman (2011) 43-4.

$90 \quad$ Rep. I no. 680; Malbon (1990) esp. 47-9, 121-36.

91 Rep. I nos 189, 667; Huskinson (1982) 20, 25-6.

92 Huskinson (1982) 46. Cf. Cartlidge and Elliot (2001) 169.

93 Acts 12.1-8. 
The scene of Peter striking the rock, which seems to have been in existence by the early fourth century, has been read as a reference to the imprisoned Peter's conversion of his gaolers, a story that appears in the texts only c. $500 .{ }^{94}$ Again, the iconography is, to say the least, ambivalent. ${ }^{95}$ It clearly evokes an episode in the life of Moses, recounted in both Exodus and Numbers, in which at the Lord's bidding Moses strikes a rock so that his rebellious people might drink. ${ }^{96}$ The biblical story was represented in early frescoes in the catacombs although there Moses generally appears without drinking companions - and it may also be depicted in a gold glass in the British Museum that shows the person striking the rock with a single kneeling figure, inscribed Hilaris in Deo cum tuis pie zezes: 'Joyfulness in God with you and yours; drink that you may live. ${ }^{97}$ On the other hand in another late fourth-century gold glass the solitary figure striking the rock is unambiguously identified as Peter, even though he is unaccompanied by drinkers. ${ }^{98}$ One plausible way to view this scene in a Roman context is to read it as intended to evoke Peter as a new Moses, a leader who guides his people in Rome to a new life and refreshes them with the waters of life. Such an understanding of the scene would render it an appropriate companion to that of Peter embarking on his passion, leading to the death that rendered him definitively a citizen of Rome. It does not necessarily provide evidence that by the early fourth century the story of Peter converting his gaolers was already current.

The various media considered here suggest that the anchoring of Peter in a specifically Roman context was already very much under way in the fourth century but that we should be wary of reading the imagery too closely in the light of later texts. What however is clear is that both Peter and Paul were adopted as local saints and patrons by the well-to-do of Rome and that Peter had especial significance for Christian members of the senatorial aristocracy such as Junius Bassus, perhaps because he was viewed as leader of the apostles and of the church in Rome. ${ }^{99}$ The emphasis in this early period is thus very much

94 See e.g. Huskinson (1982) 14-5, citing Lateran 212, Rep. I no. 41 (c. 325/350), from St Peter's; Lateran 161, Rep. I no. 6, Weizmann (1979) no. 374 (310-20), find-site unknown; Lateran 104, Rep. I no. 43 (c. 325/350), from S. Paolo fuori le mura. See also Dijkstra in this volume.

95 See for example the much-debated scenes on the Jonah sarcophagus, which probably predate the peace of the Church, where a figure striking a rock with three companions is associated with what appears to be an arrest: E. Dinkler, in Weizmann (1979), cat. no. 361; Lateran 119, Rep. I no. 35; Huskinson (1982) 13-4; Cascianelli (2017).

96 Exodus 17.1-7; Numbers 20.1-12.

97 Thomas (2015) no. 19.

98 As is another figure without any identification: Morey (1959) nos. 80-1.

99 Cf the imagery in another almost contemporaneous sarcophagus from St Peter's, Lateran 174, Rep. I no. 677. In this the centrepiece in the front is the traditio legis, with the arrest of 
on martyrdom and leadership rather than on what was to become the pivotal scene of the delivery of the keys (Matt. 16.19), which occurs only rarely.100

\section{The Embedding of Peter and Paul in the Roman Landscape}

\section{1}

\section{The Tomb Cult: the Imperial Basilicas}

One of the most striking architectural developments in the first half of the fourth century, after the peace of the Church is the group of imperial basilicas, forming large covered cemeteries, often circus-like in shape and associated with an imperial tomb. ${ }^{101}$ Cults promoted at those basilicas often achieved enduring leading status; such was the case with Agnes on the Via Nomentana, Lawrence on the Via Tiburtina, and, to a lesser degree, Marcellinus and Peter on the Via Labicana. In general, such martyrs came to eclipse figures like Sixtus II and Timothy, both of whom feature prominently on the gold glass and were clearly popular in the late fourth century but were not the primary saint of an imperial basilica. In some instances at least, we may ponder whether it was the cults that initiated the basilicas or whether imperial sponsorship through the basilicas effected a promotion of the cults.

Peter and Paul with their three locations at the Vatican, and on the Via Appia and the Via Ostiensis, formed part of this group, although the Pauline basilica was a distinctly lesser affair until the 39os, when its refoundation perhaps hastened the decline of the apostolic cult ad catacumbas. ${ }^{102}$ While Peter and Paul's importance in Biblical and patristic terms could not be questioned, it seems likely that imperial sponsorship mattered particularly in Rome. It is perhaps significant that imagery of Peter and Paul was clearly associated with martyr cults based in imperial basilicas, such as those of Agnes and Peter and Marcellinus. ${ }^{103}$

\subsection{Later Cult Sites}

By the fifth century other intramural cult sites were clearly developing in the heart of the abitato. Of these the most important was the basilica apostolorum on the Oppidan hill, the refoundation of which in the 430 s was again in part

\footnotetext{
Peter to the left and the sacrifice of Isaac left of that. The sides show the denial of Christ, with the cock on column and Peter striking the rock.

100 See Löx and Weiland in this volume; Dijkstra (2018).

101 This paragraph is based on discussion in Thacker (2007) $23^{-30}$, and the references therein. See also Liverani (2012), 107-23 and Friedrich's contribution to this volume.

102 Thacker (2012) 383-7 and references therein.

103 See above.
} 
at least an imperial enterprise. By the early sixth century and probably by the mid fifth, it had become a cult centre for Peter's chains, variously associated in the Petrine dossier with those which feature in the story of Peter's imprisonment in the Acts of the apostles and those which bound Peter during his imprisonment in Rome. ${ }^{104}$ The latter receive careful reference in Pseudo-Linus, ${ }^{105}$ and also feature prominently in the passio of Processus and Martinianus, which adds the additional detail that they fell off near a building known as the Septizodium on the Via Nova before Peter had reached the Appian gate and encountered the risen Christ. ${ }^{106}$ It is also noteworthy that in Pseudo-Linus's Acts of Paul, the Pauline chains receive a pointed reference; perhaps by the time of the Laurentian schism they were housed in the basilica on the Via Ostiense. ${ }^{107}$ The Petrine chains or at least a portion of them had already achieved a certain prominence in 419 in the famous inscription erected by Bishop Achilleus outside the walls of Spoleto, and it may be that they formed the earliest secondary relics sent to grand recipients such as the Prefect Rufinianus and, perhaps, Bishop Ambrose of Milan. Filings from the chains certainly had this function in the early sixth century. Damasus' inscription in the Vatican, ostentatiously proclaiming 'one see of Peter and one true baptism', and concluding that 'no chains hold (nulla vincula tenent) [one whom this water washes]' is perhaps alluding implicitly to Petrine legend and to the possession of these relics. ${ }^{108}$

Another apostolic cult site emerges in the sixth century on the Via Sacra. Gregory of Tours, who clearly knew the legend of the final contest with Simon

104 Thacker (2012) 398-404; Thacker (2007a) 48-50. See also a letter anciently ascribed to Jerome, De vinculis beati Petri: $P L$ 30, cols 226-31.

105 For a crucial allusion see above $\mathrm{fn} 15$, but there are two other references: [Nero] eum [Petrum] in custodia sqalidissima compedibus uinciri iussit ('Nero ordered Peter to be bound and fettered with shackles in the foulest prison'); et dum pergeret, ceciderunt illi fasciamenta ex crure demolita a compede ('and while he was going [away from prison] the bandages fell from his leg which had been damaged by the shackle'): Eastman (2015) 32-3, 42-3. Cf. the reference in Pseudo-Marcellus and its Greek counterpart to Nero's order that Peter and Paul be bound in chains: Eastman (2015) 262-3, 304-5. The Greek text also tells of Paul being bound in irons as he was taken to the place of his beheading: Eastman (2015) 306-7.

106 Tunc beatissimus Petrus dum tibiam demolitam haberet de compede ferrei, cecidit ei fasciola ante Septemsonium in via nova ('Then because Peter had a damaged shin-bone as a result of the iron shackles, his leg-bandage fell off near the Septizodium on the Via Nova'): Franchi de' Cavalieri (1953) 49; trans. Lapidge (2017) 386. For the Septizodium and the Via Nova, see Lapidge (2017) 386 fn. 17-18; Richardson (1992) 350, 417.

107 inter quos et Paulus, consuetudinarias sibi pro Christo nomine gestans cathenas, ductus est vinctus ('among these, Paul was brought and bound, bearing his usual chains for the sake of Christ'): Eastman (2015) 150-1.

108 Trout (2015) Elogium 4. 
Magus, refers to relics relating to this episode: 'still today at Rome there are two small indentations in the stone upon which the blessed apostles knelt and delivered their oration to the Lord against Simon Magus'. They were clearly valued relics, for Gregory adds that rain water collected in the indentations effected cures, ${ }^{109}$ and are presumably to be identified with the two flagstones allegedly from the Via Sacra and bearing the imprint of the apostles' knees which are today in the church of Santa Maria Nova. ${ }^{110}$ Originally, they were probably housed in the new church dedicated by Paul I (757-67) to Peter and Paul on the Via Sacra where, according to his biographer in the Liber Pontificalis, 'these blessed princes of the apostles knelt down when they poured out their prayers to our Redeemer; and on this spot even now their knee-prints can be distinguished on a very tough willow tree as a testimony to every subsequent generation to come.'111 Paul I's church, which was known until at least the end of eighth century, has disappeared, perhaps being replaced by S. Maria Nova founded by Leo IV $(847-55)$ just under a century later. It is odd, however, that the relics as described in the Liber Pontificalis seem rather different from those mentioned by Gregory and still surviving today. At all events, the stories relating to them presumably reflect the circulation of material similar to that recorded by Pseudo-Marcelllus and the Greek Acts in the sixth century if not earlier, though again there are discrepancies - the Roman texts state that the stones derived from the transformation of Simon Magus's broken body and expressly mention only Paul as praying on his knees. ${ }^{112}$

It is also possible that the Mamertinum was emerging as a place of veneration at this time. Recent archaeological investigation suggests that by the seventh century it may well have been the site of cultic activity associated with St Peter. ${ }^{113}$ As we have seen, it was presented as the location of Peter's baptism of his gaolers, first by Pseudo-Linus and then by the author of the passio of Processus and Martinianus, whose own cult site was clearly active in the sixth century. ${ }^{114}$ That passio elaborates the role of the custodia Mamertini, which it expressly associates with the Tarpeian Hill. Not only was it the prison of both Peter and Paul who together performed many miracles there, but it saw the

\footnotetext{
109 Krusch (1885) 53-4 (In Glor. Mart. cap. 27). For knowledge of the Petrine apocryphal acts in Gaul see the dog depicted on a fourth-century Gallic sarcophagus, illustrating an episode from the early conflicts with Simon Magus: Cartlidge and Elliot (2001) 167 and Dijkstra (2016) 368-9.

110 Webb (2001) 132.

111 LP no 95 (pp. 465, 466n.); trans. Davis (1992) 83.

112 Eastman (2015) 258-61; 300-5.

113 See Fortini $(2002) 522-3$.

114 Étaix et al (2005-8) no. XXXII, caps 6-7; above.
} 
baptism of others besides the guards themselves. ${ }^{115}$ The continuing impact of the story is evident from the fact that by c. 800 there was another cult site associated with Peter's water miracle, the Fons Petri, identified as outside the walls. Its origin is unknown but it presumably represents a rival location. ${ }^{116}$

The elaboration of Petrine cult sites in Rome is reflected in the contents of some of the great relic collections assembled in the Latin West by the ninth century. ${ }^{117}$ An eighth-century label from Sens records a relic de illo loco ubi $s($ anctu)s Petrus et s(anctu)s Paulus contra Simon mago orabant, evidently a reference to the imprinted stones in the Forum. ${ }^{118}$ Another such label from Sens, dating from the eighth or ninth century and recording material de petra ubi oravit s(anctu)s Petrus, relates to the cult site at the Mamertinum or at least the stories connected with it. ${ }^{119}$ More mysterious is an early eighth-century label from S. Maurice d'Agaune, identifying a relic de terra aecclesiae in qua sepultus (est) Petrus primo. This clearly alludes to a site other than the Vatican memoria and perhaps reflects ambiguities evidenced in the not entirely consistent descriptions of the saint's first resting place in the sixth-century sources. It could relate to the graves (sepulchra) in the church ad catacumbas which were shown to seventh-century visitors as the temporary resting-place of the apostles; alternatively it may derive from a site inspired by Pseudo-Marcellus's account of Peter's initial burial place under a terebinth tree next to the Naumachia on the Vatican hill. ${ }^{120}$ Clearly, however, whatever the provenance or authenticity of these relics, they surely reflect knowledge of diverse Petrine cult sites in Rome and the legends associated with them.

\section{Final Conclusions}

This paper has focused upon the Petrine cult in Rome, and in particular its embedding along with that of Paul, in the centuries after the peace of the Church as both the pre-eminent civic cult and as one of the city's local martyrial cults. The stress on Peter and Paul's joint role as chief protectors of their adopted

\footnotetext{
115 For text and discussion, see Franchi de' Cavalieri (1953). 47-9.

116 Valentini and Zucchetti (1940-53) II, 190; Steinby (1993-2000) II, 261.

117 I am most grateful to Julia Smith for drawing my attention to these relic labels and for supplying the references in the following paragraph, in advance of publication: Smith (forthcoming).

118 Bruckner and Marichal, XIX (1985), no. 682.lxxii, p. 55 .

119 Bruckner and Marichal, XIX (1985), no. 682.lxxi, p. 55.

120 Bruckner and Marichal, I (1954), no, 36, pp. 38-9; Valentini and Zucchetti (1940-53), II, 85; Eastman (2015), 266-7.
} 
city, already evident in the feast day of 29 June, reached its high point in the late fourth and early fifth century, and left an especial mark on the iconography of the sarcophagi and the gold glass. The imperial family in particular promoted the concordia of the apostles and showed a zealous devotion especially to Paul. ${ }^{121}$ The commemoration of the joint martyrdom was never entirely eclipsed but by the mid-fifth century it was accompanied in papal rhetoric by a growing emphasis on the primacy of Peter; ${ }^{122}$ that, of course is reflected in the later passion literature relating to the two apostles, except for the anomalous accounts of the separate martyrdoms, probably attributable to the Laurentian schism.

While it hardly needs saying that the official ecclesiastical hierarchy played a leading role in these developments, the cult's embedding among the senatorial aristocracy and the well-to-do also had other - imperial and local communal roots. Most importantly, the basis of all this resided not so much in official teaching about divine apostolic commission or the powers to bind and loose but on the apocryphal martyrdoms. Although not recorded in any specifically Roman version until the fifth century, they are traceable in the fourth. Clearly variable and perhaps adapted to the site upon which they focused, the early stories which inspired the fourth-century imagery may well not have been exactly those recorded in the later Roman Acta and Passiones; like the imagery itself those stories clearly developed and were invested with new meanings as martyr cult itself developed in Rome. Nevertheless, it was those texts and traditions that underpinned the cult promoted in the city and by its citizens.

\section{Bibliography}

Amore, A. 1968. Processo e Martiniano. In Bibliotheca Sanctorum X, cols 1138-40. Roma: Istituto Giovanni XXIII della Ponteficia Università Lateranense.

Bockmuehl, M. 2010. The Remembered Peter in Ancient Reception and Modern Debate. Tübingen: Mohr Siebeck.

Bruckner, A. \& R. Marichal 1954-2019. Chartae Latinae Antiquiores (118 vols). Olten: Urs Graf-Verlag.

Cartlidge D. R. \& J. K. Elliot. 2001. Art and the Christian Apocrypha. London/New York: Routledge.

121 Not only in the rebuilding of S. Paolo fuori le mura but in their sponsorship of the intramural basilica apostolorum on the Oppidan (later S. Pietro in Vincoli): Huskinson (1982) $82-3$.

122 See e.g. Huskinson (1982) esp. 85-6, 92-5, 114-23. 
Cascianelli, D. 2017. Il ritorno di Mosè. Per una rilettura delle presunte scene petrine del sarcofago di Giona. RAC 93,137-166.

Chadwick, H. 1962. Damasus and the peculiar claim of Rome to Peter and Paul. In Neotestamentica et Patristica. Eine Freundesgabe, Herrn Prof. Dr Oscar Cullmann zu seinem 6o. Geburtstag überreicht, ed. W. C. van Unnik, 313-8. Leiden: Brill.

Chavasse, A. 1973. Sancti Leonis magni tractatus septem et nonaginta (CCSL 138-38A). Turnhout: Brepols.

Dagens, C. 1982. Autour du Pape Libère. L'iconographie de Suzanne et des martyrs romains sur l'arcosolium de Celerina. Mélanges de l'École Française de Rome 78, 327-81.

Davis, R. 1992. The Lives of the Eighth-Century Popes. Liverpool: Liverpool University Press.

De Hartel, G. 1894. S. Pontii Meropii Paulini Nolani Opera (CSEL 29-30). Wien: F. Tempsky.

Dijkstra, R. 2016. The Apostles in Early Christian Art and Poetry. Leiden: Brill.

Dijkstra, R. 2018. Imagining the Entrance to the Afterlife. Peter as the Gatekeeper of Heaven in Early Christianity. In Sacred Thresholds. The Door to the Sanctuary in Late Antiquity, ed. E. B. van Opstall. Leiden/Boston: Brill 187-218.

Dolvec, F. 2015. Paulini Nolani Carmina. CCSL XXI. Turnhout: Brepols.

Donati, A. 2000. Pietro e Paolo. Milano: Electa.

Duval, Y.-M. 1992. Hymne 12. In Ambrose de Milan, Hymnes, ed. J. Fontaine, 524-46. Paris: Cerf.

Eastman, D. L. 2011. Paul the Martyr. Atlanta: Society of Biblical Literature.

Eastman, D. L. 2015. The Ancient Martyrdom Accounts of Peter and Paul. Atlanta: SBL Press.

Erbetta, M. 1975-81. Gli apocrifi del Nuovo Testamento. Casale: Marietta Editori.

Étaix, R, C. Morel \& B. Judic. 2005-8. Grégoire le Grand, Homélies sur l'Évangile (SC 485; 522). Paris: Cerf.

Fillipi, G. 2009a. Un decennio di ricerche e studi nella basilica Ostiense / cat. no. 5. In Utro (2009) 29-45.

Fillipi, G. 20ogb. Schede no. 5. In Utro (2009) 116-17.

Fortini, P. 2002. Nuovi documenti sul Carcere Mamertino (Carcer-Tullianum) quale luogo di colto Cristiano. In Guidobaldi \& Guidobaldi (2002) 503-32.

Franchi De' Cavalieri, P. 1953. Delle custodia Mamertini, Note Agiographiche 9, 3-52. Città del Vaticano: Biblioteca Apostolica Vaticana.

Freeland, J. P. \& A. J. Conway. 1993. St Leo the Great: Sermons. Washington D.C.: Catholic University Press.

Geertman, H. 2009. La genesi del Liber Pontificalis romano. Un processo di organizzazione della memoria. In F. Bougard \& M. Sot (eds). Liber, Gesta, histoire. Écrire l'histoire des evêques et des papes, de l'antiquité au XXI'e siècle. Turnhout: Brepols, 37-107. 
Giordani, R. 2001. Apollinis Templum. In La Regina (2001-8), I, 79-8o.

Grigg, L. 2004. Making Martyrs in Late Antiquity. London: Duckworth.

Guidobaldi, F. \& A. G. Guidobaldi. 2002. Ecclesiae Urbis. Atti del congresso internazionale di studi sulle chiese di Roma (IV-X secolo). Città del Vaticano: Pontificio Istituto di Archeologia Cristiana.

Huskinson, J. M. 1982. Concordia Apostolorum: Christian Propaganda at Rome in the Fourth and Fifth Centuries. A Study in Early Christian Iconography and Iconology. Oxford: British Archaeological Reports.

Krusch, B. 1885. Gregorii episcopi Turonensis miracula et opera minora (MGH, Scriptores Rerum Merovingicarum I, 2). Hannover: Bibliopolius Hahnianus.

Lanéry, C. 2008. Ambroise de Milan. Hagiographie. Paris: Institut d'Études Augustiniennes.

La Regina, A. 2001-8. Lexicon Topographicum Urbis Romae. Suburbium, a cura di V. Fiocchi Nicolai, M. G. Granino Cecere \& Z. Mari. Roma: Edizioni Quasar.

Lanéry, C. 2010. Hagiographie d'Italie (300-550). I. Les Passions latines composées en Italie. In Hagiographies V, ed. G. Philippart. Turnhout: Brepols.

Lapidge, M. 2017. The Roman Martyrs. Introduction, Translation, and Commentary. Oxford: Oxford University Press.

Leyser, C. 200o. The temptations of cult: Roman martyr piety in the age of Gregory the Great. Early Medieval Europe 9, 289-307.

Lipsius, R. A. \& M. Bonnet (1891), Acta apostolorum apocrypha post Constantinum Tischendorf, I. Leipzig: Mendelssohn.

Liverani, P. 2006a. Neronianum palatium. In La Regina (2001-8), IV, 90-1.

Liverani, P. 2006b. Phrygianum. In La Regina (2001-8), IV, 201-3.

Liverani, P. 2008. Vaticanum. In La Regina (2001-8), V, 233-4.

Liverani, P. 2012. La cronologia della seconda basilica di S. Paolo fuori le Mura. In Scavi e Scoperti recenti nelle chiese di Roma, ed. H. Brandenburg and F. Guidobaldi, 107-23. Città del Vaticano: Pontificio Istituo de Archaeologia Cristiana.

Malbon, E. S. 1990. The Iconography of the Sarcophagus ofJunius Bassus. Princeton, NJ: Princeton University Press.

McLynn, N. 2012. Damasus of Rome. A fourth-century pope in context. In Rom und Mailand in der Spätantike: Repräsentationen städtischer Räume in Literatur, Architektur und Kunst, ed. T. Fuhrer, 312-7. Berlin/Boston: Walter de Gruyter.

Moreland, M. 2016. Moving Peter to Rome. Social memory and ritualized space after 70CE. In Memory in Ancient Rome and Early Christianity, ed. K. Galinsky, 344-66. Oxford: Oxford University Press.

Morey, C. R. with G. Ferrari. 1959. The Gold Glass Collection of the Vatican Library. Città del Vaticano: Biblioteca Apostolica Vaticana.

Nestori, A. 1975. Repertorio topografico delle pitture delle catacombe romane. Città del Vaticano: Pontificio Istituto di Archeologia Cristiana. 
Nieddu, A. M. 2009. La Basilica Apostolorum sulla Via Appia e larea comiteriale circostante. Città del Vaticano: Pontificio Istituto di Archeologia Cristiana.

Richardson, L. 1992. A New Topographical Dictionary of Ancient Rome. Baltimore and London: John Hopkins University Press.

Sághy, M. 2015. The Bishop of Rome and the martyrs. In The Bishop of Rome in Late Antiquity, ed. G. D. Dunn, 37-55. Farnham: Ashgate.

Salzman, M. R. 1991. On Roman Time. The Codex Calendar 354 and the Rhythms of Urban Life in Late Antiquity. Berkeley: University of California Press.

Smith, J. (forthcoming). The remains of the saints. The evidence of early medieval relic. Early Medieval Europe.

Steinby, E. M. 1993-2000. Lexicon Topographicum Urbis Romae. Roma: Edizioni Quasar.

Thacker, A. T. 2007. Rome of the martyrs. Saints' cults and relics, fourth to seventh centuries. In Roma Felix - Formations and Reflections of Medieval Rome, ed. É. Ő Carragáin \& C. Neuman de Vegvar, 13-49. Aldershot: Ashgate.

Thacker, A. T. 2007a. Martyr cult within the walls. Saints and relics in the Roman tituli of the fourth to seventh centuries. In Text, Image, Interpretation. Studies in Anglo-Saxon Literature and its Insular Context in Honour of Éamonn Ó Carragáin, ed. A. Minns \& J. Roberts, 31-70. Turnhout: Brepols.

Thacker, A. T. 2012. Patrons of Rome: the cult of Sts Peter and Paul at court and in the city in the fourth and fifth centuries, Early Medieval Europe 20, 380-406.

Thacker, A. T. 2013. Popes. emperors and clergy at Old St Peter's from the fourth to the eighth century. In OldStPeter's Rome, ed. R. McKitterick, J. Osborne, C. M. Richardson \& J. Storey, 137-56. Oxford: Oxford University Press.

Thomas, D. T. 2015. A Catalogue of Late Antique Gold-Glass in the British Museum. London: British Museum.

Thomson, H. J. 1949-1953. Prudentius (LCL 387 \& 398). Cambridge, MA: Harvard University Press.

Trout, D. 2015. Damasus of Rome: the Epigraphic Poetry. Introduction, Texts, Translation and Commentary. Oxford: Oxford University Press.

Ussurani, V. 1932. Hegesippi qui dicitur historiae, libri V (CSEL 66). Wien: HölderPichler-Tempsky.

Utro, U. 2009. San Paolo in Vaticano. Todi: Tau Editrice.

Utro, U. 2009a. I sarcofagi paleocristiani dal complesso di S. Paolo fuori le mura / cat. no 10. In Utro (2009) 47-66.

Utro, U. 2009b. Schede no 10. In Utro (2009) 122-4.

Valentini, R. \& G. Zucchetti. 1940-53. Codice topografico dell città di Roma. Roma: Tipografia del Senato.

Verrando, G. N. 1981. Note e Documenti, Liberio-Felice. Osservazioni e rettifice di carattere storico-agiografico. Rivista di storia della chiesa in Italia 35, 91-125. 
Verrando, G. N. 1982. Le numerose recensioni della Passio Pancratii. Vetera Christianorum $19,105^{-29 .}$

Verrando, G. N. 1983. Osservazioni sulla collocazione cronologica degli apocrifi Atti di Pietro dello Pseudo-lino. Vetera Christianorum 20, 391-426.

Walker, S. 2017. Saints and Salvation. The Wilshere Collection of Gold-Glass, Sarcophagi and Inscriptions from Rome and Southern Italy. Oxford: Ashmolean Museum.

Walsh, P. G. 1975. The Poems of Paulinus of Nola. New York: Newman Press.

Webb, M. 2001. Churches and Catacombs of Early Christian Rome. Eastbourne: Sussex Academic Press.

Weizmann, K. 1979. Age of Spirituality: Late Antique and Early Christian Art, Third to Seventh Century. New York: Metropolitan Museum of Art. 